\title{
WILEY
}

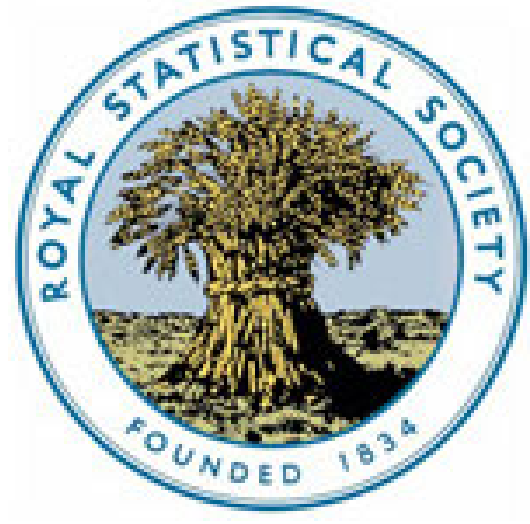

Ouvriers du Temps Passe (15e--16e Siecles). by H. Hauser

Review by: A. L. B.

Journal of the Royal Statistical Society, Vol. 69, No. 3 (Sep., 1906), pp. 603-604

Published by: Wiley for the Royal Statistical Society

Stable URL: http://www.jstor.org/stable/2339357

Accessed: 25/06/2014 00:39

Your use of the JSTOR archive indicates your acceptance of the Terms \& Conditions of Use, available at http://www.jstor.org/page/info/about/policies/terms.jsp

JSTOR is a not-for-profit service that helps scholars, researchers, and students discover, use, and build upon a wide range of content in a trusted digital archive. We use information technology and tools to increase productivity and facilitate new forms of scholarship. For more information about JSTOR, please contact support@jstor.org.

Wiley and Royal Statistical Society are collaborating with JSTOR to digitize, preserve and extend access to Journal of the Royal Statistical Society. 
very materially the anti-consumption crusade. In 1903 the numbers insured against sickness, accident, and old age were respectively $\mathrm{I}, \mathrm{I} 8$, and $\mathrm{I} 3 \frac{1}{2}$ millions; the expenditure under the same head was ro, 7 , and 5 million $£$ 's. These are vast numbers, not approached by the voluntary agencies of our country. Even in the large schemes very much is left to local effort and organisation, and voluntary associations flourish to a surprising extent. Our author does not deal with trade unions, but he devotes a very interesting chapter to workmen's secretariates, institutions for affording information and advice to workmen on trade and legal questions; in another chapter the special simple official tribunals for arbitration in minor trade disputes are described. The book is not statistical, but it should be in the hands of everyone who wishes to use the industrial or social statistics of the German Empire.

A.L.B.

9.-Ouvriers du Temps Passé (15e-16e siècles). Par H. Hauser, Professeur à la Faculté des lettres de l'Université de Dijon. xlii $+268 \mathrm{pp}$. Deuxième édition revue, corrigée et augmentée. Paris: Félix Alcan, 1906.

The first edition of this work, published at the end of 1898, appears not to have been noticed in the Statistical Journal. We gather from the preface that few important alterations have been made, but that a short concluding chapter has been added, containing (it is affirmed) the results reached in the first edition which were of too controversial a nature in 1898 for summarisation, but have been generally accepted by 1906 . The controversy, mainly as to whether the fifteenth and sixteenth centuries were a golden age for workers, is not of special interest to English readers; but the main subject of the book, the detailed description of industrial organisation in the cities of France at the time when the exclusiveness of the guilds was breaking down and the dawn of a capitalistic régime was apparent, is of great importance to students of economic history, and is treated with the lightness of touch combined with solidity of substance characteristic. of the writer's nationality. In spite of the greater rigidity of industrial organisation and the intimate restrictions by law and custom in bargaining, making, and selling, the economic laws which apply to our time were powerful enough to be felt; e.g. in face of the influx of silver, neither prices nor wages could be kept at their former level, and legal restrictions merely caused distress. Further, as our author says, "il suffit d'étudier d'un peu près l'histoire économique du $16^{\text {e }}$ siècle pour se persuader que les questions dites sociales se posaient alors, sinon avec la même extension, du moins avec la même intensité et presque dans les mêmes termes que de nos jours." He proczeds to give in great detail an account of strikes in the printing trade in Lyons and in Paris in the sixteenth century. The period dealt with in this book was one in which an industrial revolution in the organisation of labour was taking place, of which the main result is thus stated :- "Thus, in the sixteenth century, all causes united in creating a gulf, deepening day by day, between the 
class which possesses to an increasing extent the instruments of work without working, and the class which uses these instruments without possessing them." We may hazard the opinion that our author is at his best when he is least controversial.

A.L.B.

\section{0.-Women's Work and Wages: a Phase of Life in an Industrial} City. By Edw. Cadbury, M. C. Matheson, and G. Shann, M.A. Fisher Unwin, 1906. $6 s$.

Like Mr. Seebohm Rowntree, Mr. Cadbury has avoided indicating the locality of his investigation in the title of his book. This omission may be inconvenient for bibliographical purposes, and it has been treated by some reviewers as an oversight, but on consideration we are inclined to think it has been made deliberately and of set purpose. Although the district selected for intensive study is Birmingham, a city of strongly marked local characteristics and individuality, the aim throughout has evidently been to exhibit the facts, not merely in illustration of the life of the particular town, but in their relation to the social and economic forces which result in the present distribution of wealth. This method is used with success in the chapter on wages, in which the observations made by the investigators are frequently checked by and compared with the statements of the theoretical economists. Mr. Cadbury accepts the theory that wages are determined by the marginal efficiency of the earner, assuming perfect competition and full equality of competitors. He has, of course, no difficulty in showing that the assumption of equality of competitors is far from being realised in the case of women, whatever may be the case of men. The inferiority of women's wages to men's can only be partly accounted for by their less strength and efficiency; it is in great measure a result of their position in the family and society, their lack of any tradition of training for independence, and the presence of a large number of partially subsidised competitions. Mr. Cadbury has also brought out another point, which has previously, perhaps, received less attention than it merits, and that is the question of class distinction. Certain kinds of work, warehouse work, and the lighter and cleaner kinds of factory work are deemed more respectable than others, and are the resource of the better-class work-girls, and the ambition of the more aspiring in the grade below, irrespective of wages. These preferences have often a very sound basis. In some kinds of polishing, for instance, it is incidental to the work that the girls become covered with dust and grime, and "there are unfortunately still some factories where no facilities for washing are provided, and the girls have to go through the street looking quite black from the fine powdery dust" (p. 59). It is not wonderful that the trade unionists look upon the work as a degrading and demoralising occupation for women (p. 263), and that the girls from decent homes crowd into occupations of a less disagreeable character, even at lower wages. The investigators consider that about I4s. a week "is not an extravagant estimate 